Prusse, Michael. 2022. "The hero's journey as a narrative template across the media in EFL teaching.» Preprint. https://doi.org/10.5281/zenodo.6240458.

\title{
The Hero's Journey as a Narrative Template Across the Media in EFL Teaching
}

Narrative as a pervasive cultural practice across the media provides a challenging focus for English language learners. Teachers at all levels, endeavouring to explore media and culture with their students, may address the thriving practice of adapting narratives from one narrative medium to another. Children's and young adult media have been particularly productive in this respect in recent years. Bestsellers, such as the Harry Potter series (adapted from book to film and various games) or Philip Pullman's His Dark Materials (book to play and film/television series), profit from being widely known among students. Less well-known texts, by contrast, have the benefit of raising the students' curiosity and of permitting them to discover the texts at the same time as they analyse modes of adaptation.

When teachers approach media literacy within the context of teaching literature, film and modes of adaptation, a theory such as the archetypal notion of the hero's journey may function as a unifying concept both in analysing narrative across the media and in developing an understanding of extensive narrative practices. Teaching the quest motif as a basic template for a considerable amount of narrative output will equip students with tools that will enable them to accumulate cultural capital (cf. Bourdieu, 1986, p.244), which may become useful later in their lives. This contribution, based on projects carried out with students at the Zurich University of Teacher Education, will focus on three instances of what is referred to as transmedia storytelling (Ryan, 2016): Pullman's combination of a novel with a graphic novel, Spring-Heeled Jack, is followed by the adaptation of Tim Winton's Lockie Leonard trilogy as a television series and, last but not least, by Stormbreaker. 
This young adult novel by Anthony Horowitz, has been adapted both as a manga-style comic and as a motion picture.

Research in neuroscience proclaims that narrative provides the best support for the brain to retain facts, to boost memory and to learn in general (Jäncke, 2018). This is just one argument to back a focus on various forms of narrative in the context of education. In addition, narrative and storytelling are also central to numerous and very diverse cultural practices (Abbott, 2008, p.xii). Narration is, as Roland Barthes puts it, "international, transhistorical, transcultural: it is simply there, like life itself" (1977, p.79). Since there appears to exist no human culture in which narrative has no part or function, one might even be tempted to label the species as the "storytelling animal" (Gottschall, 2012) or as homo narrans (Brockmeier, 2014, p.333). Hence, the telling of stories, as well as the listening to them, can be identified as "a basic anthropological need" (Lütge, 2018b: p.184). In recent years digital media have assumed dominance to such an extent in spreading narrative in contemporary cultures "that media literacy is becoming an essential part of what teachers and students need to know in order to be competent communicators" (Quinlisk, 2003, p.39). Keeping the significance of narrative in mind, it becomes evident that it is not only essential for learning in general, but also a key aspect of teaching English as a foreign language (EFL), because it is a tremendous tool to support the language acquisition process (cf. Hall, 2016, p.465). Thus, English teachers who intend to make their learners aware of how narrative functions across diverse media have to establish the basics of literacy across the media in their classrooms.

Media literacy (or even better, multiliteracies) can be introduced by focusing on "texts" in the sense established by the New London Group (1996), meaning that these may be printed matter, in digital form or that they can exist in a "live" medium (cf. Burwitz-Melzer, 2016, p.141). This extended and comprehensive notion of "text" can be exemplified by surveying the following list compiled by Anstey and Bull (2006, pp.24-25):

- A text may comprise one or more semiotic systems;

- Texts are consciously constructed;

- Meanings are actively constructed;

- A text may have several possible meanings;

- A text may be constructed using intertextuality;

- Texts may be multimodal, interactive, linear and nonlinear. 
Regarding teacher education, the multimodal nature of much storytelling makes it manifest that "a words-only approach is no longer sufficient" (Delanoy, 2017, p.13). Even if the starting point in a classroom is a written text, a "multi-modal understanding of literature implies inclusions of texttypes such as picturebooks, comics, graphic novels, films, songs or computer games" (Delanoy, 2017, p.17). By making learners in EFL classrooms media literate, teachers open doors to other worlds that will result in "a lifetime of opportunities" (cf. Leu et al., 2004, p.1570). The contemporary world permanently confronts children and young adults with a range of texts and, as a result, young people have to acquire the ability to critically "read" and understand them (Elsner et al., 2013, p.7). They have to realize that texts are always composed in view of influencing the reader's mind-sets, beliefs and even actions (cf. Anstey \& Bull, 2006, p.23). This is not only postulated in the context of English teacher education but also, more broadly, in the UNESCO's Media and Information Literacy Curriculum for Teachers (Wilson et al., 2011) with particular reference to the teachers' ability to pinpoint 'the 'technical', 'symbolic' and 'narrative' codes of any media text" (2011, p.37). According to this curriculum, teachers ought to arrange for this type of textual analysis to occur "within meaningful contexts, rather than as an academic exercise for its own ends" (2011, p.37). Students acquire functional, visual, multimodal and digital literacy while, at the same time, analysing transcultural phenomena and training both their language awareness and their critical and reflective faculties (Elsner et al., 2013, p.8).

As Anstey and Bull declare, children's and young adult literature is particularly sensitive towards contemporary political issues and, hence, always "a product of the changing times" (2006, p.82). They posit that this makes it an extremely suitable point of departure for teachers and student teachers to learn about the concept of multiliteracies. Moreover, the established medium of the picturebook has a long tradition of multimodality by combining word and image in various and ingenious ways. If such texts are used in the classroom, one important learning goal is to guide students towards a tolerance of ambiguity, inherent in literary texts (Hall, 2016, p.459; Lütge, 2018 b , p.178). Students need to be furnished "with the critical tools" they require "to 'read' texts, to 'read' the world, and to endow" them "with the capacity to transform their world and their place in it" (Lütge, 2018a, p.302). It is also evident that the learners in EFL classrooms will need to be able to cope with different kinds of texts and it is indeed the case - as Paran and Robinson point out that many students will nowadays have experienced most narratives through the medium of film and only, to a much lesser extent, through the perusal of books (2016, p.108). Gottschall is even more drastic in his estimation of screen time when he states that by the time, they have reached adulthood, young Americans "will have spent more time in TV land than anywhere else, including school" 
(2012, pp.8-9). A respectable share of narrative across the various media is the result of adaptation from one medium to another. When the practice of adapting books for cinematic productions prevailed, reactions tended to focus on successful or unsuccessful reimaginations of the novel. In a society where visual media have gained the status that was previously mostly held by books, adaptation has to be seen more broadly as transporting narrative from one medium to another - and measure its success by asking whether the narrative convinces per se in a particular format. The essence of the process of adaptation is to keep stories fresh (Abbot, 2008, p.108), because "we are allowed to make changes and improvements when we tell stories. In fact - and this is very important to remember - we have to if we want them to live" (Pullman, 2017, pp.175-176).

The quest narrative - or, as it is also known, "the hero's journey" - is so pervasive because it is an extended version of a rite of passage that involves the stages of separation, initiation and return to the community (Prusse, 2018b, p.6). It is a concept most teachers are familiar with, at least to some extent. It can be used as a corner stone to furnish learners with an understanding as to how certain features of narrative can be observed and analysed across the media. Furthermore, accompanying the hero on an adventure allows readers to experience all sorts of things "that we would hate to happen in real life" (Coats, 2018, p.185). The long and established tradition of the quest motif in literary history (cf. Campbell, 1948) has had the effect that Hollywood tends to use it as a template to produce blockbusters (cf. Vogler, 1998). However, the template does not bear fruit when it becomes just a simple checklist for scriptwriters and it certainly must not be understood as a simple key for students to unlock all narratives. In the classroom, if introduced by means of carefully selected examples, such a template may serve as useful investigative tool when comparing narratives across the media, in particular with reference to adaptations from one medium to another. Students will immediately understand, for instance, that a book may reveal the thoughts of the protagonist or hero while a film has to resort to all sorts of more or less ingenious tricks because the camera simply cannot look inside people's heads. Since Campbell's original text contains some rather obscure vocabulary to label the various stages of the hero's journey (that Vogler relies on in his "textbook"), a simplified version of ten stages has been distilled from Vogler's model for classroom purposes (cf. Vogler, 1998, p.26):

1. The ordinary world;

2. Call to adventure;

3. The hero hesitates;

4. Friends, mentors, or circumstances convince the hero to act; 

5. A first challenge;
6. The hero is tested, confronted with enemies and supported by friends;
7. The trial or ordeal;
8. Suffering;
9. Success and reward;
10. The road back (or forward).

The hero's journey has one obvious drawback when taken to a twenty-first century classroom, namely that it is a predominantly male concept. Heroines are still by far outnumbered in narrative and, even female authors frequently choose a male protagonist over a female one (the opposite, of course, also occurs: A prominent example would be Philip Pullman who made Lyra the main protagonist of His Dark Materials). Still, to underline the choice of male figures by women, J.K. Rowling, focusing on Harry (rather than on Hermione), is arguably one of the best-known examples. Catherine Doyle, in The Storm Keeper's Island (2018), could be named as a more recent instance. Already in the prologue, the mythical "Whispering Tree" chooses the boy over the girl and establishes the precedence of a male main character. Doyle would most probably contend that since she alludes to traditional Irish legends, the hero has to be male but if critical readers continue and learn that Dagda, the magician protecting the island of Arranmore, is male and the threat to the islanders comes from Morrígan, a witch, the gender bias has to become at least a matter of discussion in the classroom (even through "strong" female characters and "weak" male characters are also part of Doyle's cast). Thus, if the hero's journey is to be introduced as a narrative pattern, the question of heroes and heroines needs to be addressed and the students have to be alerted to the significance of the uneven distribution (see also Prusse, 2014, pp.4-5). And yet, despite all the justified criticism of the concept, it is "a useful structure to have as a baseline" that learners can grasp and apply with a focus on "how authors dip in and out, fiddle with, and otherwise challenge the pattern" (Coats, 2018, p.262).

Inspired by Jonathan Bate's English Literature (2010, p.1) and by Anstey and Bull's assertion that children's literature is particularly context sensitive, first choice to introduce the quest motive would be one of the best-known modern children's books, namely Julia Donaldson's The Gruffalo (1999), illustrated by Axel Scheffler. The first two lines show the mouse confidently striding into the forest where it is spotted as potential food by a fox. This constellation immediately confirms the mouse's status as a heroic protagonist embarking on a dangerous journey (Donaldson, 1999, np). The economy of establishing the quest pattern within two lines is probably unsurpassed. While the text 
plays its part, it must not be forgotten that it interacts with Scheffler's pictures, which display the small mouse marching into the woods dominated by huge fir trees. The forest is teeming with animal life; a woodpecker underlines the height of the trees. Its natural state with fallen trees and huge rocks emphasises the heroic undertaking of the mouse. It is the combination of text and image that creates the particular spirit of adventure in this book. Many of Donaldson's texts and Scheffler's pictures display this specific skill of drawing the reader into a narrative that involves a hero or heroine, setting out on an adventure and having to submit to a series of trials (see, for instance, Room on the Broom or The Snail and the Whale). Stick Man (2008), a Christmas story, yet again launches the quest motive rapidly in the course of the four opening lines: Stick man is shown in his "family tree" where he resides with his "Stick Lady Love" and their three "stick children" (Donaldson, 2008, np). When he goes for an early morning jog, the narrator warningly admonishes him to mind the dog ...- and the hero's journey begins.

By means of these examples, the essential pattern of the quest narrative is effortlessly introduced. Perusing selected stories for children permits student teachers to increase their awareness of the great number of quest narratives they are already familiar with - across the various media. When they are confronted with a postmodern picturebook, such as Anthony Browne's Voices in the Park (1998), they may discover that the hero's narrative also very much depends on perspective - and that the tension in this particular narrative not only arises from the interaction between text and pictures, but also from the disparate views of the world that clash when four characters from different stations in society meet in a park. The unemployed working-class father, accompanying his bubbly daughter and their mongrel dog, is a stark contrast to the impeccable but snobbish upper middle-class lady that takes her shy and groomed son and her pedigree Labrador to the park. Moreover, Browne's admirable picturebook is also a prime example of intertextuality - it is not only the text and the pictures that are in a process of interaction, there are also numerous hints at other texts: the burning bush at the end of the first voice is a distinct allusion to the Bible; in the second voice, Mary Poppins can be seen flying through the sky with her umbrella; there is an elephant hiding in the trees, subtly illuminated by a lamppost that recalls its correspondent model in The Lion, the Witch and the Wardrobe. Towards the end of the second voice, King Kong can be seen on top of a high rise building while father and daughter walk home from the park. The third voice contains numerous allusions to the paintings of René Magritte: the trees and the clouds are in the shape of hats (however, Browne takes the idea but uses the shape of the hat that the character's overpowering mother wears). These links to other "texts" and contexts can be enjoyed by adult readers and may - should they wish to do so - be shared with the child. If the book is introduced 
into the classroom, teachers may just want to focus on the stories, which deal with prejudice and preconceived notions of other people or, indeed, they can draw the students' attention to the intertextual nature of Browne's book (Bland, 2013, p.230). Such "intertextual references" permit artists "to employ a kind of shorthand in their storytelling by evoking a scene, context, or theme rather than actually describing it" (Coats, 2018, p.189). The aim of such an introduction by means of picturebooks is to alert student teachers to the wealth of medial playfulness at work in this medium which will prepare them for encounters with narrative in media for older consumers.

The analysis of stories across the media by means of the quest pattern is exemplified in three short projects that address issues of media literacy and intertextuality in Swiss lower and upper secondary classrooms and that have been developed and tested with student teachers at the Zurich University of Teacher Education since 2012. As in many other countries in Western Europe, these pre-service teachers have very limited time in their curriculum to focus on culture and literature and, consequently, on the teaching of these rewarding contents in an EFL setting (see also Hall, 2016, p.463). Keeping in mind that their future pupils should also develop media literacy, these three instances of training multiliteracies with student teachers are designed in a manner that allows to adopt them for future classroom usage.

When investigating aspects of narrative in this fashion, teachers ought to keep in mind that focus is essential, in other words, the teacher chooses the texts or text excerpts to practise recognising the quest motif in various narratives but has to be aware - and share this awareness with the learners that focus also means selection and that this potentially results in a number of blind spots (Davidson, 2011, p.2). In a Swiss context, student teachers that enter the university with a state school education have proven to be reasonably proficient at analysing literary texts. By contrast, many of them have not learnt to critically review narratives in media other than in book form. This means that, apart from acquainting them with the structure of the hero's journey, they also need at least a very short introduction into reading graphic novels and comics, such as Edmunds (2014, pp.2-3). Essentially, student teachers study the interaction between words and pictures, the nature of "speech balloons, think bubbles, captions, and sound effects" and the interplay with successive frames or pictures (Pullman, 1998, p.112). While Pullman contends on the one hand that the "graphic novel vocabulary is so natural-seeming, intuitive, reader-friendly, that it seems to have come to the understanding of most of us very early in our reading" (1998, p.112), he criticizes, on the other hand, "the unspoken assumption that pictures aren't quite grown-up, or that they're only for people who don't read properly, and that clever and serious people need only consider words" 
(2017, pp.318-319). To counteract such beliefs, student teachers have to develop an appreciation of the complexity involved in the combination of words and images in graphic novels.

The first project, aimed at alerting student teachers to the close links between novels and graphic novels, focusses on Philip Pullman's Spring-heeled Jack (cf. also Prusse, 2014; 2018b). As the previous paragraph shows, the author himself is a great fan of comics and graphic novels and, with this particular text, he creates what Kimberley Reynolds has called a hybrid (1994, p.66) - in other words a multimodal narrative. Pullman based the character on a model from a Victorian pennydreadful that features a kind of "Batman" who can jump over houses because of the springs in his boots. The novelist turns the dubious original into a positive figure that helps the three main protagonists of the novel, two girls and a boy, after their breakout from an orphanage, to escape the clutches of an assortment of villains and supports them in their quest to find their father. The various stages of the quest pattern, from leaving their ordinary surroundings through tests, suffering and triumph, to embracing a new community (a variation of the model), are clearly discernible in the text. Readers of Spring-heeled Jack soon perceive that the story advances both in the text and in the pictures; hence, they have to pay attention to either in order to get the full story. Furthermore, the novel toys with various forms of intertextuality. In an interview Pullman admits that storytellers are thieves since "every story has been told before" (Lacey 2012) and, in Spring-heeled Jack, he cheerfully alludes to numerous other texts by means of quotations, most of them acknowledged, some of them to be discovered by those who read the text carefully. Multiliteracy thrives on such hybrid texts that require intertextual knowledge to get the multi-faceted meaning of the text (Anstey $\&$ Bull, 2006, p.31). One of the main subtexts is indicated with the name of the arch villain in Pullman's text, namely "Mack the Knife", a character that originally featured in John Gay's The Beggar's Opera and in its German adaptation by Bertold Brecht, The Three Penny Opera. When Mack makes his first appearance in the story by creeping out of a dustbin, there is a joke in the picture by David Mostyn (best-known for his artwork for The Beano): the scruffy, scavenging cat, prowling next to the bin, thinks "Big Mack" when it sees the criminal. This is a reference to another, much more mundane "Mac" in the contemporary world of the intended audience of Pullman's novel.

In its combination of comic-book features and "traditional" prose the novel succeeds in alluding to a whole universe of additional texts, from Alexandre Dumas to popular music hall songs and advertising posters for the US army; from Charles Dickens to the Moomins and to the Franglais created by Miles Kington. The latter wrote comic dialogues in Franglais, a mixture of French and English, which were a regular feature in Punch magazine and which Kington also published as 
collections in books such as Let's Parler Franglais (1984). Basically, readers have to understand the French vocabulary but need to continue to think in English to enjoy this particular kind of humour. Thus, Pullman's menu in Franglais (1991, p.49) can be a great source of enjoyment, especially in an environment where French and English are taught as second and foreign languages, such as Switzerland (Prusse, 2014, p.13).

Spring-heeled Jack allows students to recognize the various steps of a quest narrative and to encounter postmodern playfulness by means of intertextuality, a blend that makes the narrative appealing both to young readers (the story is exciting and funny) and to adults who will enjoy and appreciate the numerous allusions. Teachers may choose whether they want to share their intertextual knowledge with their pupils or, alternatively, split the class into groups and have them research the various influences. When the learners report back to their classmates, this might - at least in some cases - result in a stimulus to explore some of these other texts.

The second project relies on Tim Winton's Lockie Leonard series (three novels 1990-1997), their adaptation for television in 2007, and a historical engraving that depicts Captain Cook at Botany Bay, taking possession of Australia for the British Crown. The novel trilogy describes how an Australian teenager matures as a result of moving from Perth to Winton's fictitious Angelus (aka Albany WA), of going through the pangs of first love, and of riding some rather dangerous waves on his surfboard. The skilful adaptation of the novels for television is not only enjoyable for a teenage audience but also for adults - a typical feature of contemporary movie and television productions for children (cf. Anstey \& Bull, 2006, p.30). Winton's texts anticipate the television makers' use of the hero's journey: every book contains at least one episode, in which the protagonist, Lockie, rides his surfboard in risky circumstances. These vignettes can be seen as penetrating reflections on Lockie's life; he dives into the sea, faces challenging waves (and creatures such as sharks), overcomes these obstacles, is shaken by his emotions including fear and horror (catharsis), and returns to the beach, renewed and ready to tackle his life again. Unlike the television episodes, which generally start with a short review of the challenge, in the novel these moments are usually placed not quite at, but close to the beginning and, again, at the end. Every episode of the TV series is structured according to the quest pattern (Cohen, 2009, p.60). The numerous repetitions, both in the novels and in the television series, make them ideally suited for the classroom. Depending on the number of episodes they view, students have repeated opportunities to discern and analyse the pattern of the quest narrative.

As in Spring-heeled Jack before, the Lockie Leonard novels and their television adaptations are highly intertextual (cf. Prusse, 2018b). Moreover, there is even a "soundtrack" provided by Winton 
who quotes from lyrics by Sting and Midnight Oil. This soundtrack is "modernized" by the directors of the TV series who use artists such as Jebediah, Little Birdy and Spiderweb. The songs that accompany the books and the television series offer an additional choice to teachers as materials that they can share with their learners in the EFL classroom.

The opening television episode begins with Lockie's first surf in his new hometown. In the novel series, this particular episode actually only occurs at the outset of the second book, Lockie Leonard Scumbuster (1993). Lockie's ride ends with him falling off his board, which strikes him painfully in the genitals. He crawls onto the beach where he lies writhing in pain when his new friend, Egg, struts across the sand and looks down on him. The television directors chose to cast Egg as an Aborigine and, hence, the scene on the beach becomes an ironic juxtaposition of Samuel Calvert's iconic engraving (1865), which depicts Captain Cook as the proud conqueror taking possession of the Australian continent with a thundering salute while the native Australians are cringing in fear or running away (cf. Prusse, 2018a; 2018b). Bringing these texts into the classroom, i.e. fiction in both written and TV-series format and historical "fiction" in the form of a painting, they become resources to teach interculturality, series and seriality, and narrative as cultural practice.

In the third project the student teachers work with the novel Stormbreaker (2000) by Anthony Horowitz, which was adapted twice in 2006, namely as a movie and as a graphic novel.

Stormbreaker relates the first adventure in the Alex Rider series, which consists of thirteen volumes and a collection of short stories to date. The protagonist is a teenager who is enlisted by MI6 in missions where adults would be suspicious - and, as most student teachers immediately realize when reading or viewing one of these texts, replete with allusions to James Bond. A teenage spy fits the bill extremely well when it comes to applying the pattern of the hero's journey - and again, this can be done in all three media products, in the novel, the movie and the graphic novel. This particular project has student teachers become aware of how adaptation works across the media. The procedure sketched out here is more extensively described in two German publications (Prusse, 2018b; Prusse, 2020). Basically, it uses a vignette, which the student teachers first read. The four pages from the novel describe how Alex discovers his uncle's BMW in a scrapyard. Puzzled that the car is riddled with bullet holes, he climbs into it to hide when someone approaches. Unfortunately for him, the vehicle is destined to be destroyed in the crusher and, in the remainder of the passage, the students discover how he can narrowly escape from this threatening situation. Next, the students are asked to work in groups and transform the scene by means of stick figures into a comic and discuss their resulting adaptations (Prusse, 2018b; 2020). In the subsequent stage they are shown two pages from the graphic novel which display the crushing of the car in representative panels and 
graphically underline the sound of the crusher with expressive lettering. Student teachers may compare their own attempts at adaptation with the version of the professional manga artists and get some inspiration regarding creative licence in this process. Last, but not least, student teachers survey the corresponding scene from the movie - it is just two minutes long - and discover what features of the book (or the graphic novel) are transferred to the screen in this particular adaptation. Since a television series based on the second volume of the Alex Rider novels, Point Blanc (2001) is forthcoming, there is ample room for further explorations into transmedia analyses using this particular hero.

In a context where the teaching of literature is provided with rather limited temporal resources, the introduction of the quest motif by means of picturebooks and its analysis in the three projects briefly summarized above provides succinct opportunities for student teachers to engage with modes of narrative across the media. The primary aim is for them to develop a more profound perception of literacy as "taking part in a dynamic dialogue with the text" (Bland, 2018, p.42) and to draw inspiration from these activities to teach multiliteracies in their future classrooms; secondly, to help them and their future pupils understand the vibrant nature of narrative as it unfolds in a variety of contexts and media and, last but not least, to enable them to support their learners as they strive towards becoming multiliterate personalities.

\section{Bibliography}

Browne, A. (1998). Voices in the Park. London: Picture Corgi/Random House, 1999.

Calvert, S. (1865). Engraving of a historical painting by J. A. Gilfillan (1859), Captain Cook taking possession of the Australian continent on behalf of the British Crown 1770 for the Illustrated Sydney News. National Library of Australia: http://nla.gov.au/nla.obj-135699884

Donaldson, J. \& A. Scheffler (1999). The Gruffalo. Oxford: Macmillan.

Donaldson, J. \& A. Scheffler (2008). Stick Man. London: Alison Green/Scholastic.

Doyle, C. (2018). The Storm Keeper's Island. London: Bloomsbury.

Horowitz, A. (2006). Stormbreaker: An Alex Rider Adventure. New York: Speak.

Horowitz, A. (2006). Alex Rider - Stormbreaker. The graphic novel. Adapt. A. Johnston, Illus. K.

Damerum \& Y. Takasaki. New York: Philomel.

Kington, M. (1984). Let's Parler Franglais. Harmondsworth: Penguin. 
Lockie Leonard (2007). [TV series] Dir. T. Tilse, W. Blair, R. Hodgman, J. Bogle \& P. Templeman, Goalpost Pictures.

Pullman, P. (1991). Spring-Heeled Jack. New York: Alfred A. Knopf.

Stormbreaker (2006). Dir. G. Sax, Samuelson Productions.

Winton, T. (1990). Lockie Leonard, Human Torpedo, Camberwell (Victoria): Penguin, 2007.

Winton, T. (1993). Lockie Leonard, Scumbuster, Camberwell (Victoria): Penguin, 2007.

\section{References}

Abbott, H.P. (2008). The Cambridge Introduction to Narrative. Second Edition. Cambridge: Cambridge University Press.

Anstey, M. \& G. Bull (2006). Teaching and Learning Multiliteracies: Changing Times, Changing Literacies. Kensington Gardens SA: Australian Literacy Educators’ Association/ALEA.

Barthes, R. (1977). Image - Music - Text. Essays selected and translated by S. Heath. New Yok: Hill \& Wang.

Bate, J. (2010). English Literature: A Very Short Introduction. Oxford: Oxford University Press. Bland, J. (2013). Children's Literature and Learner Empowerment: Children and Teenagers in English Language Education. London: Bloomsbury.

Bland, J. (2018). Brian Selznick's The Invention of Hugo Cabret as a Mentor Text for Deep Reading in ELT. Anglistik: International Journal of English Studies, 29.1: 41-53.

Bourdieu, P. (1986). The Forms of Capital. In J. G. Richardson (ed.). Handbook of Theory and Research for the Sociology of Education. New York: Greenwood Press, 241-258.

Brockmeier, J. (2014). Narrative as Cultural Practice. In C. Leung \& B. V. Street (eds.). The Routledge Companion to English Studies. Abingdon: Routledge, 333-343.

Burwitz-Melzer, E. (2016). Text- und Medienkompetenz. In E. Burwitz-Melzer, G. Mehlhorn, C. Riemer, K.-R. Bausch \& H.-J. Krumm (eds.), Handbuch Fremdsprachenunterricht (pp. 141144). 6 completely revised and expanded edition. Tübingen: Francke.

Campbell, J. (1949). The Hero with a Thousand Faces. Princeton: Princeton University Press, 2004. Coats, K. (2018). The Bloomsbury Introduction to Children's and Young Adult Literature. London: Bloomsbury.

Cohen, D. (2009). 'Lockie Leonard: Growing Up Can Be a Hairy Business', Idiom, 45.1: 57-63.

Davidson, C. N. (2011). Now You See It: How Technology and Brain Science Will Transform Schools and Business for the 21st Century. New York: Penguin.

Delanoy, W. (2017). Picturebooks, Comics and Graphic Novels: New Perspectives for Literature and Language Teaching. In K. de Rocha, A. Haidacher-Horn \& A. Müller-Caron (Eds), 
Picture That? Picturebooks, Comics and Graphic Novels in the EFL Classroom. Research and Teaching Implications. Graz: Leykam, 13-27.

Edmunds, T. (2014). How to Read a Comic. In: J. Elder. Reading with Pictures. Kansas City: Andrews McMee, 2-3.

Elsner, D., Helff, S. \& B. Viebrock (2013). Films, Graphic Novels \& Visuals: Developing

Multiliteracies in Foreign Language Education - An Interdisciplinary Approach. Berlin: LIT.

Gottschall, J. (2012). The Storytelling Animal: How Stories Make Us Human. Boston: Houghton Mifflin Harcourt.

Hall, G. (2016). Using literature in ELT. In G. Hall (ed.). The Routledge Handbook of English Language Teaching. London: Routledge, 456-469.

Jäncke, L. (2018). Perspektive Neurowissenschaft. ilz 8. Lehrmittelsymposium 2018: Was ist gute Bildung? 25 January 2018.

https://ehrmittelkoordination.ch:8043/video/p/api/video.php?a=display \&f=k2jHff\&ac=MHwy OXwXOXww\&vt=360p

Lacey, H. (2012). The Inventory: Philip Pullman. The Financial Times, 16 March.

http://www.ft.com/cms/s/2/10f13e1e-6d6f-11e1-b6ff-00144feab49a.html

Leu, D.J., Kinzer, C.K., Coiro, J.L. \& Cammack, D.W. (2004). Toward a Theory of New Literacies Emerging from the Internet and Other Information and Communication Technologies. In R.B. Ruddell \& N.J. Unrau (Hrsg.), Theoretical Models and Processes of Reading (pp.1570-1613). Fifth Edition. Newark: International Association of Reading.

Lütge, C. (2018a). Digital, Transcultural and Global? Reconsidering the Role of Literature in the EFL Classroom. In A.-J. Zwierlein, J. Petzold, K. Boehm \& M. Decker (Eds), Anglistentag 2017 Regensburg: Proceedings. Trier: WVT, 299-309.

Lütge, C. (2018b). Literature and Film - Approaching Fictional Texts and Media. In C. Surkamp \& B. Viebrock (Eds), Teaching English as a Foreign Language: An Introduction. Stuttgart: Metzler, 177-194.

Paran, A. \& P. Robinson (2016). Literature - into the Classroom. Oxford: Oxford University Press. Prusse, M. C. (2014). "Every Story Tells a Story That Has Already Been Told”: Intertextuality and Intermediality in Philip Pullman's Spring-Heeled Jack and in Kevin Brooks' iBoy, Children's Literature in Language Education (CLELE), 2.1: 1-21. http://clelejournal.org/wpcontent/uploads/2014/05/Prusse-Every-Story-Tells-a-Story-That-Has-Already-Been-Told.pdf

Prusse, M. C. (2018a). Transmedial Reading: Tim Winton's Lockie Leonard. In Using Literature in English Language Education: Challenging Reading for 8-18 Year Olds, ed. J. Bland. London: Bloomsbury, 121-137. 
Prusse, M. C. (2018b). Die Heldenreise als transmediale Erzählschablone im Englischunterricht. www.leseforum.ch 3:

\section{https://www.leseforum.ch/sysModules/obxLeseforum/Artike1/645/2018 3 de prusse.pdf}

Prusse, M. C. (2020). Transmediales Erzählen im Fokus: «Close Reading» Aktivitäten als Beitrag für zukunftsorientierten Englischunterricht. Babylonia 2 (2020): forthcoming.

Pullman, P. (1998). Picture Stories and Graphic Novels. In K. Reynolds \& N. Tucker (Eds), Children's Book Publishing in Britain Since 1945. Aldershot: Scolar, 110-132.

Pullman, P. (2017). Doemon Voices: Essays on Storytelling, ed. S. Mason. Oxford: David Fickling. Reynolds, K. (1994). Children's Literature in the 1890s and the 1990s. Plymouth: Northcote House. Ryan, M.-L. (2016). Transmedia narratology and transmedia storytelling. artnodes (18): DOI:

\section{http://doi.org/10.7238/a.v0i18.3049}

Quinlisk, C. C. (2003). Media Literacy in the ESL/EFL Classroom: Reading Images and Cultural Stories. TESOL Journal, 12.3: 35-40.

Vogler, C. (1998). The Writer's Journey: Mythic Structure for Writers. Studio City (CA): Michael Wiese.

Wilson, C., Grizzle, A., Tuazon, R., Akyempong, K., Cheung, C.-K. (2011). Media and Information Literacy Curriculum for Teachers. Paris: UNESCO, 